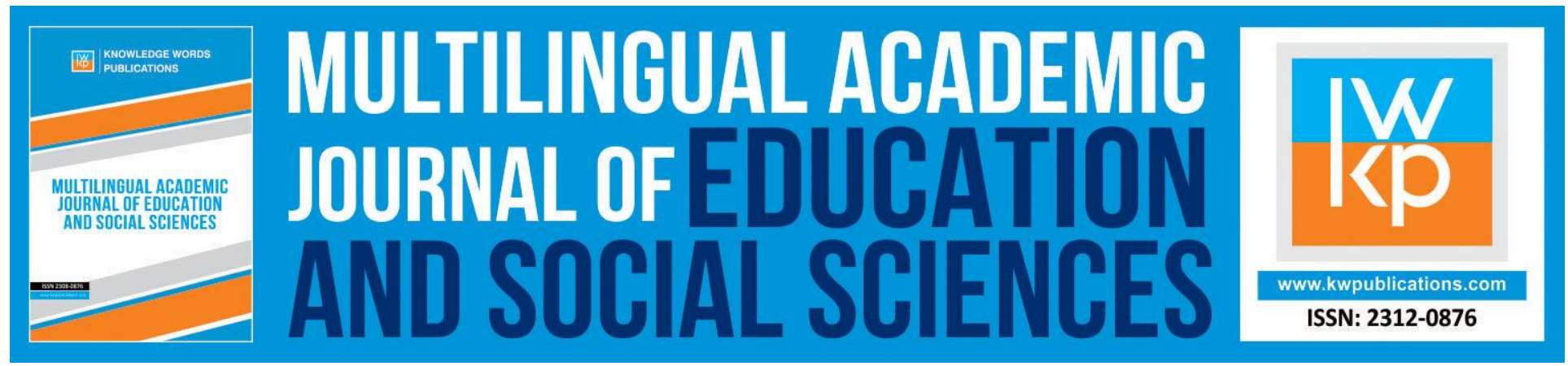

\title{
In-service Training Needs of English Language Teachers and Vocational Education
}

\author{
Dora Chostelidou, Eleni Griva
}

To Link this Article: http://dx.doi.org/10.46886/MAJESS/v1-i1/7285

DOI:10.46886/MAJESS/v1-i1/7285

Received: 01 January 2013, Revised: 02 February 2013, Accepted: 18 March 2013

Published Online: 27 April 2013

In-Text Citation: (Chostelidou \& Griva, 2013)

To Cite this Article: Chostelidou, D., \& Griva, E. (2013). In-service Training Needs of English Language Teachers and Vocational Education. Multilingual Academic Journal of Education and Social Sciences, 1(1), 1-18.

\section{Copyright: (C) The Authors 2013}

Published by Knowledge Words Publications (www.kwpublications.com)

This article is published under the Creative Commons Attribution (CC BY 4.0) license. Anyone may reproduce, distribute, translate and create derivative works of this article (for both commercial and non-commercial purposes), subject to full attribution to the original publication and authors. The full terms of this license may be seen

at: http://creativecommons.org/licences/by/4.0/legalcode

Vol. 1, No. 1, 2013, Pg. 1 - 18

https://kwpublications.com/journals/journaldetail/MAJESS

JOURNAL HOMEPAGE

Full Terms \& Conditions of access and use can be found at https://kwpublications.com/pages/detail/publication-ethics 


\title{
In-service Training Needs of English Language Teachers and Vocational Education
}

\author{
Dora Chostelidou, Eleni Griva
}

Applied Linguistics at the Aristotle University of Thessaloniki, Faculty of Education University of

Western Macedonia

\begin{abstract}
The study was designed with the aim to identify and analyse the training needs of English language teachers employed in the context of Vocational Education in Greece. Moreover, the opinions of the directors of Vocational Training Institutes (IVTs) were obtained in acknowledgement of their role as the 'key' stakeholders involved in the organization and development of any future In-service Training (INSET) programmes. The research tools employed comprised a questionnaire, administered to seventy-six English for Specific Purposes (ESP) teachers while semi-structured interviews were also conducted with eight directors of Vocational Training Institutes in order to gain further insights into the teaching context. The findings of the study highlighted the need for the development and implementation of training programmes focusing on the perceived INSET needs of ESP practitioners employed in Vocational Education, which indicates the implications of the study for the Greek Education Policy framework.

Keywords: Teacher Training, Vocational Education, English Language Teachers, Training Needs.
\end{abstract}

\section{Introduction}

Teacher training is a dynamic and evolutionary process which aims to inform teachers of changes concerning teaching methodology and provide them with the necessary tools for updating their knowledge. It would also seem reasonable to say that there is a great need for effective INSET provision in the field of Vocational Education as a part of educational policy and training in any democratic society.

Training of teachers is among the most demanding issues in professional development. In this context, Continuing Professional Education (CPE), which is becoming a growing arena of practice for teachers, aims to help teachers to keep abreast of new knowledge, maintain and enhance their competence to acquire positive attitudes towards teaching. Teachers are then encouraged to apply new knowledge and skills in their practice (Craft, 2000; Loughran, 2010; Queeny, 2000).

Continuing Professional Education must be sustained as an essential aspect of teacher professional development because of the following reasons (Papastamatis \& Panitsidou, 2009). Indeed, there is a greater demand than ever before due to the enhanced emphasis placed on the 
MULTILINGUAL ACADEMIC JOURNAL OF EDUCATION AND SOCIAL SCIENCES

Vol. 1 No. 1, 2013, E-ISSN: 2308-0876 @ 2013 KWP

need for the effectiveness of education because of the increasing number of teachers being recruited without having sound knowledge base for teaching in the specific sector, in Greece, and partly because of technological advancement. Another reason for the importance attached to professional development is the recent emphasis on the accountability and therefore the need for schools to provide evidence for effective teaching and learning (Caillods, 2013; Pellicer \& Anderson, 1995). Although research on teacher education is still in the early stages of development in Greece, some evidence is provided about the nature and process involved in practice which seems to help teachers develop their conceptions, understandings, practices and dispositions for teaching (LePage et al., 2005).

It should be considered that many teacher education programmes have been criticized for being too theoretical, having little connection to practice, offering fragmented

and incoherent courses and lacking in clear orientation and principles, as well as not considering teachers' needs (Abednia, 2012; Darling-Hammond et al., 2005; Sešek, 2007).

\section{Vocational Education and Training in Greece}

The General Secretariat of Lifelong Learning (GSLLL) was established under L.3879/2010 (actually renaming the "General Secretariat of Adult Education" established by L.2909/2001), under the aegis of the Greek Ministry of Education, Religion and Lifelong Learning. The responsibilities of GSLLL comprise the design and implementation of Lifelong Learning Policies, the development of the National Lifelong Learning Programme, along with the supervision and coordination of all bodies and programmes operating in the field of general adult education as well as initial and continuing vocational education and training, among which, the Institutes of Vocational Training (IVT).

The Institutes of Vocational Training (IVTs) were established in the framework of the National System for Vocational Education and Training, Law 2009/1992 following the changing needs of the labour market at both the national and the local levels in Greece. After the completion of their training, IVT graduates receive a "Certificate of Vocational Training", which entitles them to sit the certification exams and acquire a "Diploma of Vocational Training", recognised in all EU countries (P.D. 231/1998). The number of Vocational Institutes has risen significantly since they were first introduced and today there are 93 Public IVTs providing training in as many as 200 specializations (http://www.gsae.edu.gr/index.php/diekpinakas).

Each of the training years comprises two semesters, the autumn and spring semesters each one including fourteen weeks of training. Teaching of English has been included on the learners' weekly timetable for the whole period of study - four semesters- and takes place for three hours every week. Teachers, in the context of Public Vocational Institutes, are appointed on the basis of their qualifications, pedagogic skills, and experience. They are not employed on a permanent basis, but on a contractual basis for the duration of an academic semester and are paid by hour. It should be stressed that the great majority of the teachers employed in the public Vocational Institutes have not been trained to cope with the demands of an ESP teaching context as most of them are qualified as English for General Purposes (EGP) teachers (Griva, Chostelidou \& Tsakiridou, 2008).

Thus, many teachers are unaware of the diversified role of the ESP teacher and the complex nature of issues, which are all closely related with ESP (Zhu \& Liao, 2008). Among them 
MULTILINGUAL ACADEMIC JOURNAL OF EDUCATION AND SOCIAL SCIENCES

Vol. 1 No. 1, 2013, E-ISSN: 2308-0876 @ 2013 KWP

are the procedures involved in the development of a needs analysis project and the transformation of the data obtained from it into course and syllabus design (Dudley-Evans \& St. John, 1998; Bosher \& Smalkoski, 2002; Long, 2005), the development of new subject-specific teaching materials (Belcher, 2004). It also involves the adaptation of already existing materials as the available materials do not seem to match the learners' needs. Cooperation is also required between ESP teachers and subject specialists, which is often referred to as team teaching (Belcher, 2009; Richards \& Farrell, 2005). Thus, it is acknowledged that the English language teachers in the context of Vocational Education need special training in ESP principles and methods in order to be able to cope effectively with all aspects of ESP (Wu \& Badger, 2009).

The fact that they are hired to teach different specializations in every semester also makes it difficult for them to familiarize themselves with a certain subject area. The lack of subject-specific knowledge and the absence of INSET programs set obstacles which require a lot of time and conscious effort on the part of teachers to overcome.

\section{Study}

\section{Rationale and Aims of the Study}

Very little research has been conducted on issues related to in-service training in postsecondary education within Greece and consequently very little attention has been paid to teachers' training needs. The study was designed to focus on the basic training issues related to the needs of English language teachers in the sector of post-secondary education since it is widely acknowledged that improving the quality of teaching is an educational priority and teacher training is sustained as an indispensable constituent of 'empowering' teachers to deliver effective and efficient ESP courses,. Taking into account the fact that the identification of teachers' training needs is one of the 'key' factors in designing training programmes (Darling-Hammond, 2006; West, 1994), the present study set itself the purpose of identifying and recording the training needs of English language teachers operating in the context of State Vocational Institutes.

As part of the research process, the viewpoints of the directors of Vocational Institutes on issues related to planning and organising INSET programmes were recorded, since they are regarded as the 'key' stakeholders in any future attempt for provision of teacher training. The study sought for answers to the following questions:

a) what are the teachers' perceptions of ESP teacher roles? b) what are their viewpoints on practical arrangements with respect to the organization of future ESP training programmes? c) what are their training needs and their expectations regarding the content of future ESP training courses? d) how is the present situation perceived by the directors? e) what are the directors' viewpoints concerning INSET planning and organizing and f) what are their suggestions about certain practical arrangements for future INSET courses?

\section{Participants}

The participants involved in the study were seventy six (76) ESP teachers (89\% female and 11\% male), employed in State Vocational Training Institutes in Northern Greece. Their ESP teaching experience varied. The least experienced teachers had been working from one semester to five years (68\%), while the most experienced teachers for more than five years (32\%). A significant percentage of the participants (36\%) hold a master degree. Eight (8) directors of Vocational Education Institutes in Northern Greece participated in the study. Their management 
MULTILINGUAL ACADEMIC JOURNAL OF EDUCATION AND SOCIAL SCIENCES

Vol. 1 No. 1, 2013, E-ISSN: 2308-0876 @ 2013 KWP

experience in IVTs ranged from one year to four years, and their teaching experience ranged from ten to seventeen years.

\section{Instruments}

The questionnaire, specifically designed for this research, was the basic instrument used for the elicitation of information from the teachers (Brown, 2001). The questionnaire, administered to teachers, consisted of 12 items, including closed type questions that were organized into three major areas:

The first section was entitled 'personal data' and it consisted of items related to personal details about: a) FL instructors' teaching experience, b) their qualifications, c) their current place of teaching and d) their training experience and the evaluation on attended training courses. The second section was concerned with: a) the reasons for attending training courses and b) their preferences about planning and organising training programmes (course attendance, course length, institutions and trainers). The third section consisted of items related to the instructors' needs related to 'the components of a training course'. It was divided into two basic parts: a) needs related to training on theoretical issues and $b$ ) needs related to training on teaching methodology issues.

In addition, semi-structured interviews were designed and conducted with eight directors of IVTs in order to gain more meaningful insights into the situation (Fig. 1).

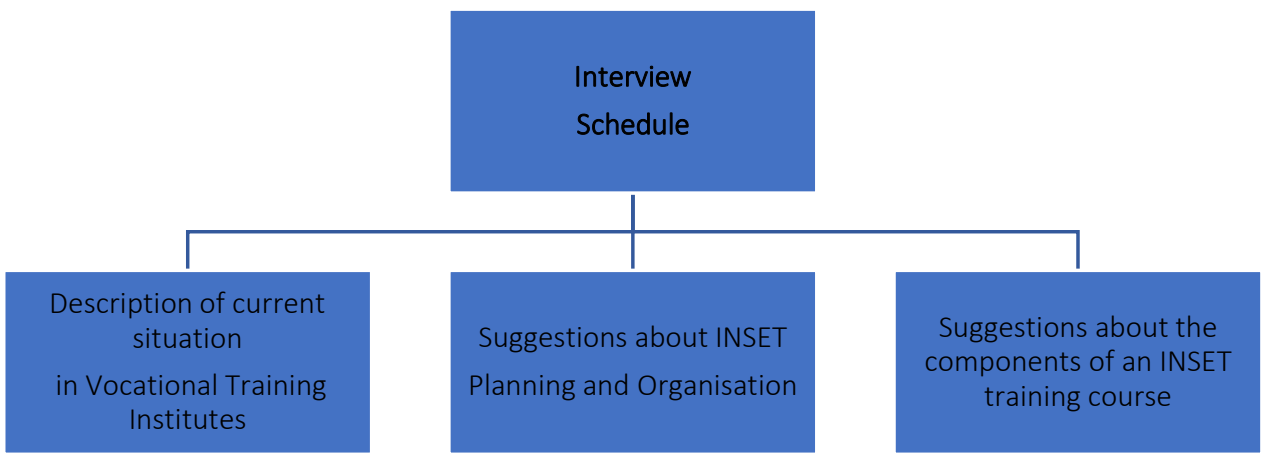

Fig. 1 Interview schedule

Data derived from the questionnaires were analyzed by using descriptive statistical methods. Chi-square-test $\left(\mathrm{X}^{2}\right)$ was used to test differences if any, in the teachers' training needs according to their demographic characteristics. Moreover, the techniques of t-test and ANOVA were performed in order to identify differences in ranking the various items reflecting teachers' viewpoints on training courses.

The interview data, which were analysed qualitatively, underwent the process of data reduction involving first and second level coding as well as pattern coding. Codes resulted in groups of categories (Miles \& Huberman, 1994). Then, similar concepts with common characteristics were clustered into themes (see Table 1).

\section{The Results: Teachers' Views on the Qualities of ESP Teachers}

The teachers were asked to express their views on the qualities needed for an ESP teacher to provide efficient in the ESP classroom. They considered that the most important skill of an 
effective ESP teacher is undoubtedly 'knowledge of specialized aspects of ESP teaching' (40.5\%). Participants were very sensitive (31\%) to 'understanding student needs and difficulties' and believed that it is important for teachers to be able to respond effectively to their students' needs. Furthermore, they seemed to rank highly the level of 'Language for Specific Purposes' (17.6\%) and 'modern teaching methods' (16.4\%). However, they showed little interest in 'making adaptations and improvements in the existing syllabus', since only $1.4 \%$ of the participants ranked it as their first priority (Fig. 2).

Significant differences $\left(F_{2.64}=4.221, p<0.05\right)$ were identified concerning the 'understanding of students' needs and difficulties' as the novice ESP teachers ranked it as more important: 1-5: $m=2.26$, $s d=1.36,6-10: m=2.38 \mathrm{sd}=1.5,10+: \mathrm{m}=4.23$, $\mathrm{sd}=1.39$. Also, significant differences were identified between the teachers concerning their studies in 'knowledge of specialized aspects of ESP teaching' $(t=2.108, d f=72, p<0.05)$; the teachers who hold a master degree ranked it lower $(m=2.84, s d=1.89)$ in contrast to the rest of the participants who do not hold such qualification $(m=2.16, s d=1.4)$. Similarly, there were significant differences between the teachers with a Master's degree and those who do not hold one with regard to their studies in 'adaptation and improvement of the present syllabus' ( $t=3.096, d f=71, p<0.005)$; more precisely, the former ranked it higher $(m=4.11, s d=1.05)$ than those without a Master's degree $(\mathrm{m}=3.23, \mathrm{sd}=1.34)$.

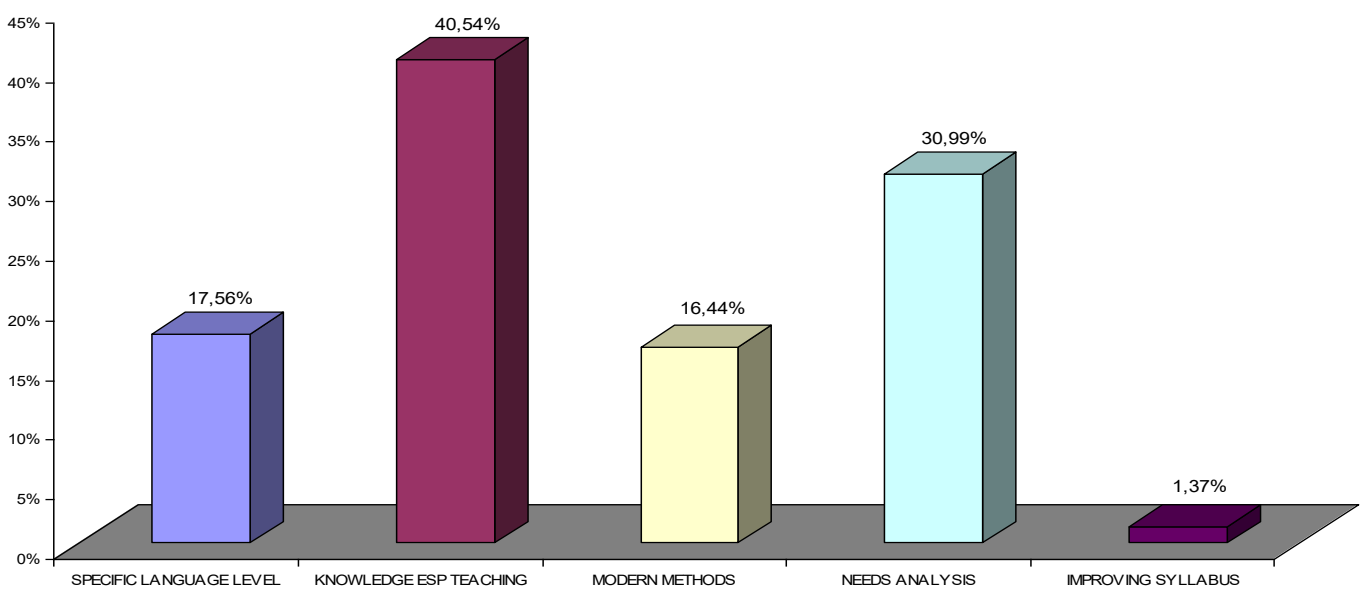

Fig. 2 The skills of an effective ESP teacher

\section{Teachers' Stance on INSET Training Aspects}

The most popular incentive $(38.4 \%)$ for the teachers at issue in order to attend training courses appeared to be the improvement of 'language teaching methods'. The second priority of the teachers (29.7\%) was to 'be trained on aspects of ESP syllabus' while their third priority $(29.6 \%)$ was to be provided with the opportunity for an 'update on ESP teaching methods'. They also viewed the 'strengthening of self-esteem' as meriting an important level of priority (4.2\%). It should be noted that the majority of the sample showed little interest in 'promoting professional growth' (1.4\%), financial incentives - extra payment on salary (2.8\%), and exchanging ideas with colleagues (1.4\%), (Figure 3). 
However, despite the fact that the majority of the participants in the study showed little preference for 'promoting professional growth', there were significant differences ( $t=2.108$, $\mathrm{df}=72, \mathrm{p}<0.05)$ between the teachers holding a Master's degree who ranked it highly $(\mathrm{m}=4.6$, $s d=1.63)$ compared to those with a Bachelor degree $(m=5.65, s d=0.95)$.

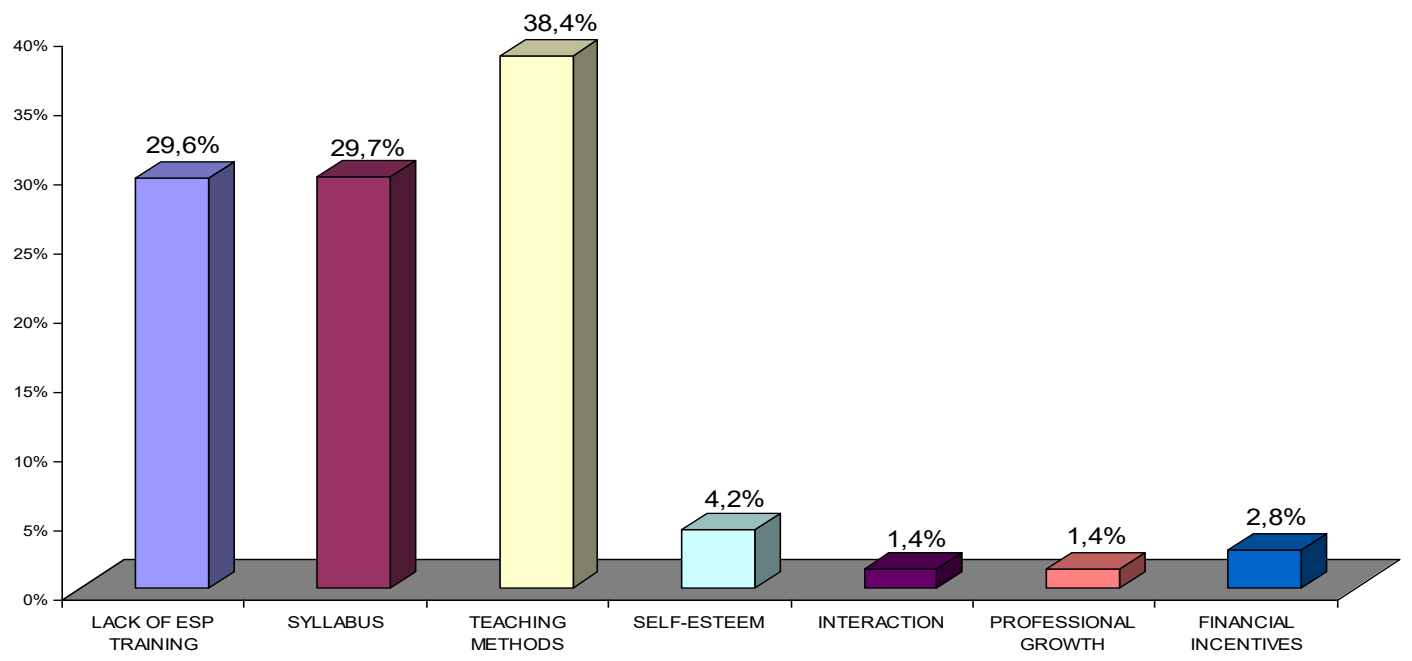

Fig. 3 Teachers' stance on INSET training aspects

\section{Teachers' Views on Organizing Training Courses}

The majority of the English language teachers employed in IVTs expressed their preference for the training provided to be held during two-week courses (54.8\%) scheduled just before the beginning of each semester (68.1\%). A significantly lower percentage of them were interested in participating into a monthly course $(25.4 \%)$ which could take place during the summer holidays so as to offer flexibility concerning attendance options.

The universities were recorded as the main training institution (46.7\%) responsible for organizing and running training programs. The active involvement of institutional conveyors was also considered essential with the Ministry of Education being both the main representative of educational policy and sponsor and the General Secretariat of Lifelong Learning (GSLLL) (19.4\%) as the institution to take up the scientific responsibility and the undertaking of educational program design and implementation. Moreover, the teachers showed their preference $(18.3 \%)$ for special teacher training colleges to undertake the organization and conduct of programs.

When asked about the staff they would like to become involved in future training, the teachers expressed the view that they could benefit from having qualified colleagues as their trainers. In addition, they wished to receive their learning from highly qualified academic staff. More precisely, the highest percentage (46.6\%) was given to fellow teachers with special qualifications and experience. A very high percentage (30.7\%) was assigned to university lecturers; however, lower votes were cast for trainers from the British Council and TESOL (14.1\%) as well as from the GSLLL (11.4\%).

There were statistically significant differences between novice teachers and those with a long working experience regarding their first preference for training staff selection $\left(F_{2,64}=3.757\right.$, 
$p<0.05)$. More precisely, teachers with ESP teaching experience showed their preference to British Council trainers 1-5: $\mathrm{m}=2.91$, $\mathrm{sd}=0.95,6-10: \mathrm{m}=2.57 \mathrm{sd}=0.79,10+: \mathrm{m}=2.08, \mathrm{sd}=1.19$.

It should be highlighted that 'workshops' received the highest percentage (61.3\%) as the most preferred teaching method. 'Micro-teaching' was the second most favoured teaching approach chosen by the teachers (17.6\%) and the 'lectures' followed (16.9\%). It is surprising to note that a large number of teachers $(16.9 \%)$ were in favour of the lecturing method although so much criticism of its usefulness has been made by many educationalists recently. 'Collaboration with colleagues of other subject disciplines' gained the lowest percentage from ESP teachers (7\%).

Moreover, statistically significant differences were identified between the language teachers with training experience and those who have not attended training seminars $(t=2.26$, $\mathrm{df}=70, \mathrm{p}<0.05)$. In particular, the former showed a greater preference to 'microteaching' $(m=1.89, s d=0.63)$ compared to those with no training experience $(m=2.27, s d=0.79)$.

\section{Teachers' Needs related to the Components of a Training Course}

Regarding the components of a training course, the vast majority of the teachers involved in the study expressed their training need in 'modern methods of teaching English for Specific Purposes' (78.38\%) along with a high number of participants who stated that 'motivating students' (75\%) and 'identifying students' needs' (65.71\%) are important elements for their teaching practice (Figure 4). The teachers who hold a Master's degree ranked 'identifying students' needs' lower than those who hold a Bachelor degree though ( $x 2=9.028, d f=2, p<0.05)$.

Furthermore, 'ESP vocabulary' (63.77\%), 'materials design' $(72.2 \%)$ and 'theories of adult learning' (58.33\%) received significant percentages. Statistically, there were significant differences resulting from the teachers' training experience; The teachers who had no training experience declared higher needs (88.6\%) in 'theories of adult learning' than the rest of the participants $(62.1 \%)(x 2=8.715, \mathrm{df}=2, \mathrm{p}<0.05)$. Moreover, the teachers who had no training experience declared higher needs (72.1\%) in 'ESP vocabulary' than the ones who have attended seminars (48\%) (x2=7.577, $\mathrm{df}=2, \mathrm{p}<0.05)$ (Fig.4).

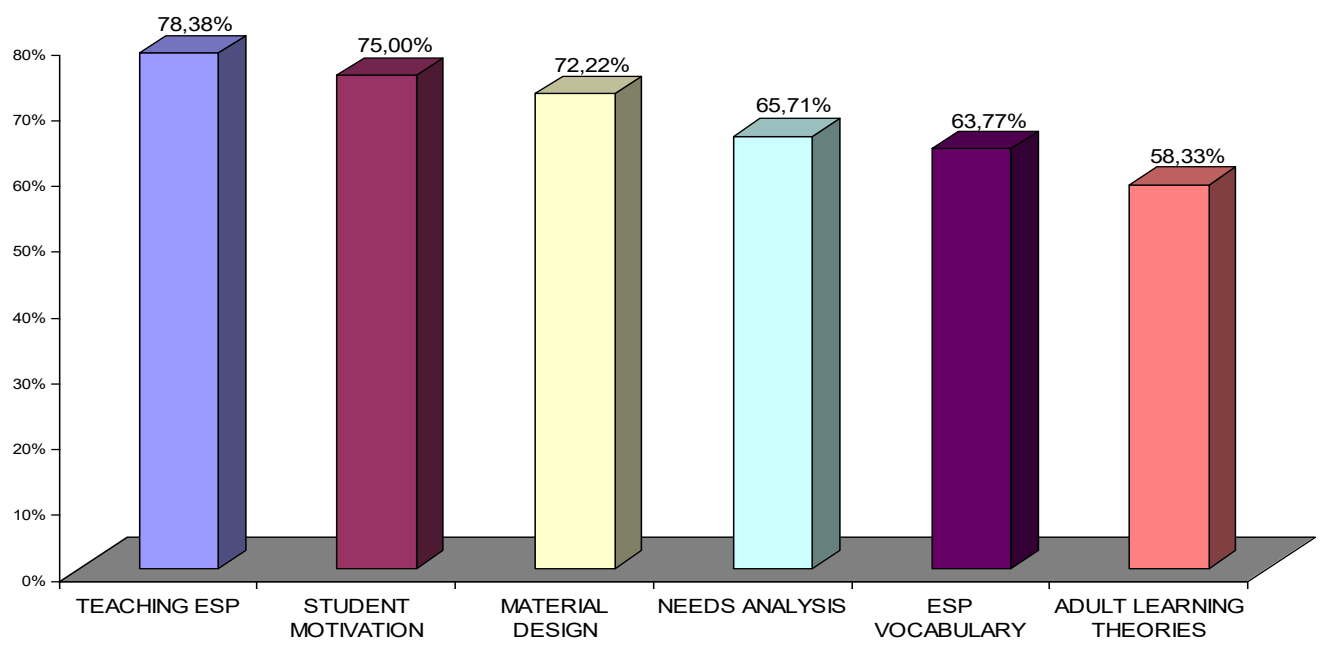

Fig. 4 The components of a training course 
A significant percentage of the participants (53.42\%) indicated their need to receive training in 'designing activities' and a substantial number of the participants (50\%) emphasized their need in 'lesson planning and preparation'. Furthermore, they stated a high training need in 'teaching the productive skills' (52.78\%) and 'teaching the receptive skills' (52.17\%), (Fig. 5). The English language teachers who had no training experience reported higher needs (63.6 \%) in 'teaching the productive skills' $(63.6 \%)$ than the rest of the participants $(33.3 \%)(x 2=6.335, d f=2$, $\mathrm{p}<0.05)$.

In contrast, 'evaluation' and 'testing' which were the least popular components among the respondents of the questionnaires were scored highly by $37.14 \%$ and $35.71 \%$ of the teachers respectively. The teachers who had no training experience declared higher needs (45.5\%) in training concerning 'student evaluation' than those who have attended seminars and scored 'very little' on the rating scale (41.7\%), (Fig. 5).

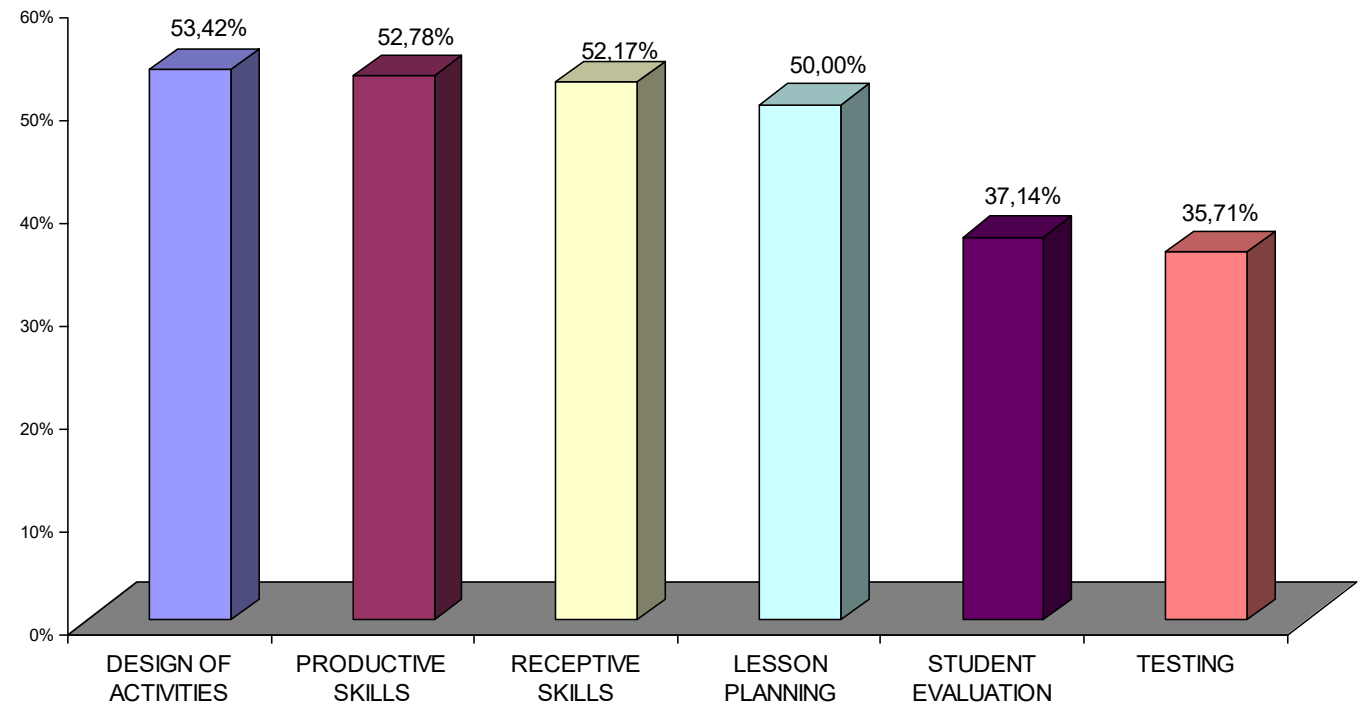

Fig. 5 The components of a training course

\section{Teachers' Expectations from a Training Course}

In order to identify the potential outcomes of an effective training course the respondents were presented with four statements to choose from. A significant number of the teachers ranked 'applying modern ESP teaching methodology' (69.3\%) first. They welcomed the 'understanding the principles of modern ESP teaching methodology' as second priority (16.7\%) and 'training on the principles and content of an ESP course/syllabus' as third priority (Fig. 6).

Although the participants showed little preference to 'reflection on teaching practice' $(5.7 \%)$, there were significant differences $\left(F_{2.63}=4.251, p<0.05\right)$, as the novice ESP teachers considered it as more important and ranked it higher: $1-5: \mathrm{m}=3.2$, $\mathrm{sd}=0.94,6-10: \mathrm{m}=3.25 \mathrm{sd}=1.17$, 10+: $m=4, s d=0$. It was indicated that there was a significant difference between the teachers with regard to their teaching experience in 'understanding the principles of modern ESP teaching methodology' $\left(F_{2.65}=3.865, p<0.05\right)$; the more experienced teachers ranked it higher: 1-5: $m=2.7$, $\mathrm{sd}=1.03,6-10: \mathrm{m}=2.5 \mathrm{sd}=0.93,10+: \mathrm{m}=1.85, \mathrm{sd}=0.86$. 


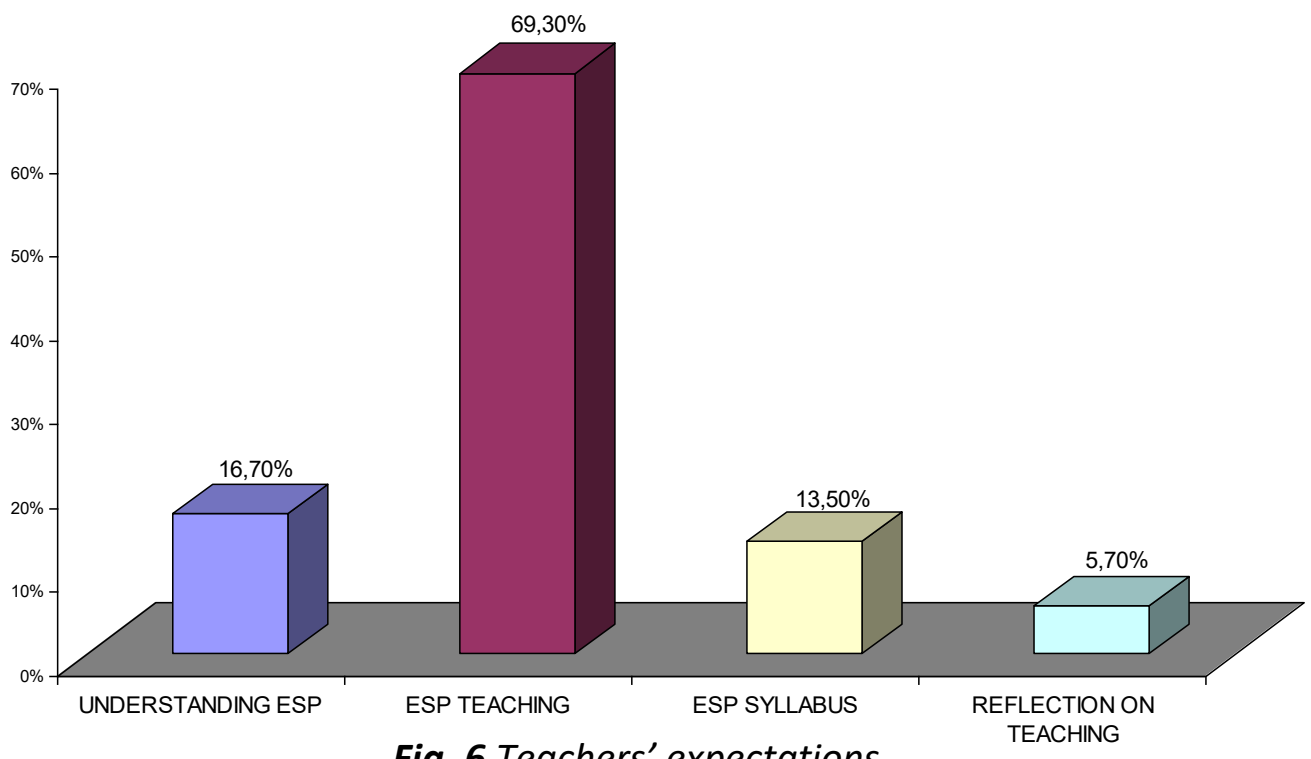

Fig. 6 Teachers' expectations

\section{Results: The Directors' Interview Results}

The data from the directors' interviews, after being coded, resulted into 28 codes, which were grouped into eight (8) categories classified into three basic themes: a) Current situation; b) INSET planning and organisation; c) Components of a training course (Table 1).

Table 1 The Directors' Interviews Data

Themes/categories

Codes-Coding patterns

\section{A. CURRENT SITUATION IN VOCATIONAL EDUCATION}

LATESPE=Lack of Teacher Specialisation

1. Inefficient Aspects of the Present Situation
TENTRSUSPI $=$ Teachers not Trained in Subject-specific Issues

LASUSPMA=Lack of Subject-specific Materials

INESPTEA=Inefficient ESP Teaching

\section{B. INSET PLANNING AND ORGANISATION}

2. Urgent Need for INSET Provision

3. Focused Teacher Programmes
IMNEPLTR=Immediate Need for Planning Training

COBTEANE=Courses based on Teacher Needs

DEITRPRO=Decentralisation of INSET programmes

CEINSEPR $=$ Centralised INSET Programmes 


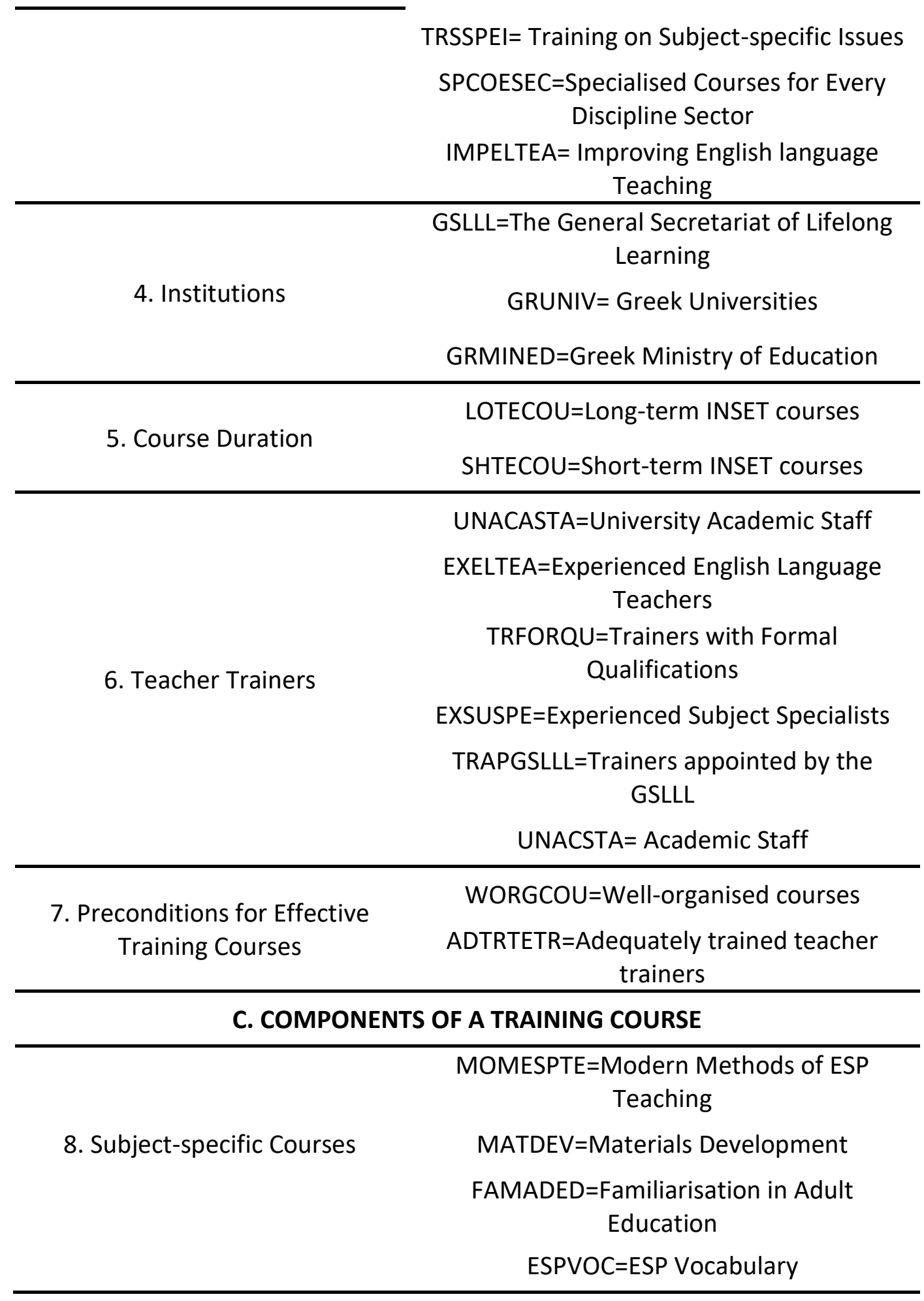

\section{Current Situation}

The descriptive account of the current situation with respect to INSET provision in Vocational Education as presented by the directors is regarded rather disappointing. All of them made reference to the fact that INSET is actually not provided to ESP teachers and expressed the 
MULTILINGUAL ACADEMIC JOURNAL OF EDUCATION AND SOCIAL SCIENCES

Vol. 1 No. 1, 2013, E-ISSN: 2308-0876 @ 2013 KWP

view that the vast majority of English language teachers in the context of Vocational Education were not trained in terms of the subject-specific issues of the disciplines they teach. From the total of their answers, it was revealed that the 'immediate need for provision of training' is considered undoubted for all directors, who explicitly stated that both the absence of training in 'ESP teaching' and the inadequate training in 'teaching adult learners' are the major causes for the problematic aspect of the present situation.

Some 'negative' aspects of the present situation which resulted from the absence of a well organised INSET programme were highlighted by the directors: a) Inefficient ESP teaching, not really related to the content of specific disciplines, since teachers are assigned to teach ESP courses without any initial training. The directors felt that the subject-specific content is alien to teachers' previous experience, mainly because of the lack in their formal ESP qualifications; $b$ ) lack of subject-specific material and unsuitability of the content of the courses. As a result, ESP course content is not clearly specified and both materials and activities are not specifically oriented towards the subject content of the disciplines.

\section{Planning and Organising INSET Courses}

The participants underlined the immediate need for designing and organizing training courses for the language teachers in the ESP context at issue. More precisely, the directors stated the need for training the language teachers in subject-specific areas by means of planning 'focused training courses. They pointed out both the necessity and importance of specialized training courses for every discipline sector on the basis of language teachers' needs, which was stated as the basic factor for the effective planning and implementation of an INSET course.

According to their opinions, a number of principles govern the design of a future INSET programme: a) Relevance of the content and practical arrangements which are in accordance with the needs of the target group of teachers', b) collaboration, which incorporates cooperation between ESP teachers and other stakeholders through all the stages and processes of INSET, c) compensation, as it attempts to compensate for the deficiencies ESP teachers concerning the teaching they offer, d) centralization and decentralization of INSET planning and implementation. Emphasis was placed on the necessity of the development of an INSET training programme, which ought to be designed 'in a centralized way' and carried out in a decentralized dimension, based on local conditions, in order to supply equal training opportunities to all teachers. In particular, the GSLLL is reportedly needed to assume the responsibility for the design of programmes centrally, but has to move towards a decentralized system at least in the execution of the INSET courses. The directors strongly advocated the decentralization of INSET activities with regional Institutes of Vocational Training to serve as regional centers of excellence and work in close cooperation with universities.

It was considered imperative to proceed to the configuration of a general framework and the co-ordination of training activities by a central institution, preferably the GSLLL in cooperation with a Greek University or with the 'Greek Ministry of Education'. This way, the institution will allow and encourage decentralization of training activities. The university was proposed as the main training institution having the prestige, the infrastructure and the teaching staff. The active involvement of institutional conveyors is also considered essential with the GSLLL being both a main representative of training policy and sponsor and as an institution to take up the responsibility and the undertaking of programme planning design. Furthermore, they stressed 
MULTILINGUAL ACADEMIC JOURNAL OF EDUCATION AND SOCIAL SCIENCES

Vol. 1 No. 1, 2013, E-ISSN: 2308-0876 @ 2013 KWP

the need for the language teachers' participation in the process of designing the INSET programme and identifying the components of the courses which, according to the directors, could be organized at the beginning of every semester.

Concerning the potential teacher trainers, the directors showed high preference for the university academic staff who were perceived as the most effective trainers to run INSET courses. Moreover, they had a marked preference for a) English language teachers, who have to be chosen and posted on the basis of their formal qualifications, as well as their teaching experience and detailed knowledge of practical constraints of the situation. The trainers ought to have broad theoretical knowledge and at the same time teaching experience so as to be effective while training, b) experienced professionals with special qualifications who cooperate with the GSLLL.

The interviewees also suggested that training should be held before the initiation of a semester, so that the English language teachers could prepare before the teaching assignment. Concerning the course duration, it appeared that they preferred INSET courses of duration of up to one-month. There also seemed to be some preference for short-term programmes, to last one or two weeks and be carried out on a regular basis, which could provide teachers with more chances in their attempt to update and upgrade ESP knowledge.

\section{Components of a Training Course}

The teachers' development in terms of the improvement of 'ESP teaching methods' appeared to be the most popular aspect of the directors' opinions for training teachers, since they strongly believed that that there is a need for teachers to renew and improve their ESP knowledge and to update ESP teaching techniques. According to them, the teachers' effectiveness is heavily dependent on the following factors:

a) Specialized knowledge of the target domain language; Teachers have to provide their students with an effective way of realising the scientific knowledge through the English language.

b) Subject-discipline knowledge and expertise in the techniques and methods of ESP language teaching. The problem lies with the fact that the teachers are supposed to become 'experts' in a subject discipline and put this expertise into practice in the foreign language without any previous training in it. Teachers with little or no scientific background may fail to fully comprehend subject specific texts and will inevitably feel insecure.

c) Knowledge in the field of adult education and training. Most interviewees expressed the wish for teachers' to receive adequate training which is in agreement with the principles of 'adult education'. They considered an understanding of how adult students learn as the starting point for ESP teaching, since learning and teaching in such contexts are determined by the learners themselves.

d) Grounding in material development. The directors stated that there is no predetermined syllabus or course book, which the English language teachers are required to follow and the ESP course content is not clearly specified. For that reason, most of the ESP teachers experience difficulties when either selecting or producing teaching materials and they need proper guidance and training. All tasks involved in planning the course, selecting the materials, teaching and coordinating are 'required' to be performed by the ESP teachers themselves. However, these tasks call upon particular skills and capabilities, which the English language teachers have not acquired during a pre-service training stage. 
MULTILINGUAL ACADEMIC JOURNAL OF EDUCATION AND SOCIAL SCIENCES

Vol. 1 No. 1, 2013, E-ISSN: 2308-0876 @ 2013 KWP

\section{Discussion, Reflections and Conclusions}

The research data illustrated a number of issues, which have to be considered and should provide a framework for educational policy development and implementation. Also, it signposts for future investigations are provided. In particular, the following issues were raised: a) the absence of an INSET policy in the context of Vocational Institutes in Greece; b) the need for focused INSET policy and plans to be introduced in the context considered; $c$ ) the organizational aspects of INSET programmes $d$ ) the components of the future training courses.

First of all, the major issue which emerged from the present study is the absence of INSET programmes in the context of Vocational training Institutes. It was highlighted that the INSET policy which is referred to in the framework of the National System for Vocational Training has actually never reached the implementation phase. In fact, the vast majority of the participants, Vocational Institute directors and ESP teachers, strongly show their dissatisfaction with the current situation and expressed the need for INSET courses with a clear focus on ESP/EOP (English for Occupational Purposes) to be ultimately established in the context at issue.

Another aspect, which is typical of the current situation and has been indicated both by the directors and the teachers, is that the majority of ESP teachers in the context considered though well educated and with some teaching experience have simply been adapted from ELT (English Language Teaching). Therefore, they are unaware of the diversified roles of the ESP teacher (Graves, 2000) and the effort which has to be undertaken in order to perform adequately as "organizer, assessor, prompter, participant, controller as well as knowledge-resource" (Zhu \& Liao, 2008: 91) which are all regarded functional roles of an ESP teacher. In consequence, the teachers' need for continuing their education in order to update their knowledge and renew their teaching methods (Darling-Hammond, 2006) was strongly expressed by a significant percentage of the participants.

The majority of the participants in the study stressed the need for the provision of focused INSET programmes which would familiarize the teachers with the underlying principles of ESP (Dudley-Evans \& St John, 1998), would facilitate them in providing efficient and effective ESP teaching in the language classroom thus, increasing their professional confidence (Almabekova, 2010) and in effect raising the status of the English language in Vocational Education. It is equally significant that for both teachers and directors 'training' constitutes a process of challenge for the development of the professional knowledge, skills, competence and interests, a process of reinforcement, which contributes to the familiarization with new ESP teaching methods and to the change of attitude and the role of ESP teacher itself (Lawton, 1990).

A further major issue emerged is the necessity for the development of subject-specific INSET courses as ESP courses which by nature have a clear orientation in content to "specific disciplines" in order to be able to effectively tackle its specificity nature (Dudley-Evans \& St John, 1998). Nevertheless, it has been suggested by the directors that teachers should attend training seminars organized on the basis of broad sectors or fields which involve an engagement with the core of a subject area and not on the basis of specific disciplines or specializations as the former arrangement seems both practical and realistically attainable in terms of organizational issues.

Furthermore, the significance of the provision of on-going INSET which is responsive to the teachers' needs was strongly emphasized as its impact on the effectiveness of any language course is widely acknowledged. In effect, there is a call for INSET programmes, which take place on a regular basis and are planned centrally but executed decentrally. The decentralization of 
MULTILINGUAL ACADEMIC JOURNAL OF EDUCATION AND SOCIAL SCIENCES

Vol. 1 No. 1, 2013, E-ISSN: 2308-0876 @ 2013 KWP

training activities, the negotiation of needs among teachers, trainers, and policy makers as well as the systematic planning and the evaluation of each individual training programme constitute aspects for the provision of ESP teacher training (Chostelidou, Griva \& Tsakiridou, 2009) in the context of Greek Vocational Training Institutes. In this respect, the Institutions which are highly regarded by the participants for organizing INSET programmes are the GSLLL along with the Ministry of Education in cooperation with the Greek Universities.

In addition, a number of suggestions about the focus of the components of INSET courses in the context of IVTs were provided by the directors and teachers who agreed that INSET training should primarily aim to satisfy the needs as perceived by teachers themselves (Kleinsasser, 2013) in order to properly address the needs of their students (Sava, 2009). Among the suggested components emphasis has been laid on the realization of INSET programmes with a high specificity level in terms of language, skills at the macro- and micro-level, discourse, and genres related to particular disciplines or specializations (Dudley-Evans \& St John, 1998).

The development of an ESP vocabulary component was also highly regarded since ESP teaching involves the teaching of courses "related in content to particular disciplines" (Strevens, 1988 in Dudley-Evans \& St John, 1998: 3). It cannot be overlooked however, that ESP teachers are supposed to be knowledgeable in content areas despite the fact that they have only been trained in terms of linguistic knowledge rather than discipline related knowledge (Sava, 2009). Therefore, they have to be properly trained so as to become familiar with subject specific vocabulary so that they are able to perform a number of subject-specific tasks (Celani, 2005) in relation to their students' professional skills.

Moreover, given the distinct nature of ESP courses, it is considered imperative that ESP teachers become familiarized with needs analysis (West, 1994) "the key concept or cornerstone of ESP" (Dudley-Evans \& St John, 1998). However, needs analysis is regarded a rather complex process, thus, special emphasis needs to be laid in providing adequate training which clarifies its underlying principles as well as methodological implications. The establishment of the needs analysis process in an INSET framework is expected to provide a strong justification for all the decisions made on the part of ESP teachers with respect to course design specifications (Basturkmen, 2010; Richards, 2001).

Finally, it has to be acknowledged that a high degree of consensus was identified in the directors' and the teachers' perception according to which INSET courses are needed in the cluster of items related to teaching methodology, which, however, does not have exclusively theoretical character (Bronkhorst, et al., 2011; Lawton, 1990). Both theory and practice are of crucial importance for language teacher education (Crandall, 2000; Newby, 2003), which should involve a variation of learning techniques aiming at the trainees' active participation (Kumari, 2012; Wang, 2013). Furthermore, the adult education framework (Kroth 2000; Rogers, 1996) is also considered as essential element to be dealt with in INSET programmes, since adult learners share a variety of characteristics (Mackeracher, 2004; Griva et al, 2010), which have certain implications for ESP course design specifications. We believe that an awareness of the distinct characteristics brought in the language classroom by ESP learners is a pre-requisite for effective instruction.

The impact of teacher training on optimizing teaching and learning opportunities in the ESP classroom need hardly be argued as the distinct characteristics and the nature of ESP require awareness on the part of the teachers as to the diversified roles and the modern instructional 
MULTILINGUAL ACADEMIC JOURNAL OF EDUCATION AND SOCIAL SCIENCES

Vol. 1 No. 1, 2013, E-ISSN: 2308-0876 @ 2013 KWP

needs assumed of them. For this reason, the introduction of an INSET policy to address the training needs of ESP teachers operating in the context of Vocational Education and Training Institutes seems more timely than ever.

\section{References}

Abednia, A. (2012). Teachers' professional identity: contributions of a critical EFL teacher education course in Iran. Teaching and Teacher Education, 28, 706-717.

Almabekova, O. A. (2010). Reflective Teaching in ESP. Journal of Siberian Federal University. Humanities \& Social Sciences, 3(3), 462-475.

Basturkmen, H. (2010). Developing courses in English for Specific Purposes. London: Palgrave Macmillan.

Belcher, D. (Ed.) (2009). English for Specific Purposes in theory and practice. Ann Arbor, MI: University of Michigan Press.

Belcher, D. (2004). Trends in teaching English for Specific Purposes. Annual Review of Applied Linguistics, 24, 165-186.

Bosher, S., \& Smalkoski, K. (2002). From needs analysis to curriculum development: designing a course in health-care communication for immigrant students in the USA. English for Specific Purposes, 21(1), pp. 59-79.

Bronkhorst, L. H., Meijer, P. C., Koster, B., Vermunt, J. D. (2011) Fostering meaning-oriented learning and deliberate practice in teacher education. Teaching and Teacher Education, 27(7), 1120-1130.

Brown, J. D. (2001). Using surveys in language programs. Cambridge: Cambridge University Press. Caillods, F. (2013). Let's Emphasise Teachers' Professionalisation. Achieving Quality Education for All Education in the Asia-Pacific Region: Issues, Concerns and Prospects, 20 (1), 97-101.

Celani, M. A. (2005). A retrospective view of ESP teacher education programme. In M.A.A. Celani, A. F. Deyes, J. L. Holmes, \& M. R. Scott (eds.), ESP in Brazil: 25 years of evolution and reflection (pp. 393-408). Sao Paolo: Mercado de Letras.

Chen, Tsai-Yu. (2000). Self training for ESP through action research. English for Specific Purposes, 19(4), 389-402.

Chostelidou, D., Griva, E., \& Tsakiridou, E. (2009). Record of the training needs of ESP Practitioners in Vocational Education. In A. Tsangalidis (ed.), Selected papers from the $18^{\text {th }}$ International Symposium of Theoretical and Applied Linguistics. Aristotle University of Thessaloniki (pp. 131-144). Thessaloniki: Monochromia.

Craft, A. (2000). Continuing professional development. London: Routledge Falmer.

Crandall, J. (2000). Language teacher education. Annual Review of Applied Linguistics, 20, 34-55.

Darling-Hammond, L. (2006). Powerful teacher education: lessons from exemplary programs. San Fransisco: Jossey-Bass.

Darling-Hammond, L., Hammerness, K., Grossman, P., Rust, F., \& Shulman K. (2005). The design of teacher education programs. In L. Darling-Hammond \& J. Branford (eds.), Preparing teachers for a changing world: what teachers should learn and be able to do (pp. 390-441). San Francisco, CA: Jossey-Bass.

Dudley-Evans, T., \& St. John, M. (1998). Developments in English for Specific Purposes. Cambridge: Cambridge University Press.

Graves, K. (2000). Designing language courses: a guide for teachers. Boston: Heinle \& Heinle. 
MULTILINGUAL ACADEMIC JOURNAL OF EDUCATION AND SOCIAL SCIENCES

Vol. 1 No. 1, 2013, E-ISSN: 2308-0876 @ 2013 KWP

Griva, E., Papastamatis, A., Valkanos, E., \& Tsakiridou, E. (2010). A study of the in-service training needs of the instructors employed in Greek Second Chance Schools. In A. Papastamatis, E. Valkanos, G. Zarifis \& E. Panitsidou (eds.), E-Book Conference Proceedings of ESREAReNAdET Inaugural meeting: 6-8 November 2009, University of Macedonia, Thessaloniki, Greece (ISBN 978-960-8396-54-8).

Griva, E., Chostelidou, D., \& Tsakiridou, E. (2008). Foreign language skills development in Vocational Education: bridging the gap. Paper presented at $15^{\text {th }}$ AlLA Conference, 26-30 August 2008, Essen, Germany.

Kroth, M. (2000). Life mission and adult learning. Adult Education Quarterly 50(2), 134-149.

Kumari, K. N. (2012). Modern and innovative practices and impact on teacher education. International Journal of Multidisciplinary Educational Research, 1 (2), 430-435.

Lawton, D. (1990). The future of teacher education. In N. Graves (ed.), Initial teacher education: policies and progress. London: London Education Studies.

LePage, P., Darling-Hammond, L., Akar, H., Gutierrez, C., Jenkins-Gunn, E., \& Rosebrock K. (2005). Classroom management. In Darling-Hammond and Bransford J (eds.), Preparing Teachers for a changing world: what teacher should learn and be able to do (pp. 327-357). San Francisco, CA: Jossey-Bass.

Long, M. H. (2005). Methodological issues in learner needs analysis. In: M. H. Long, (ed.), Second language needs analysis (pp. 19-76). Cambridge: Cambridge University Press.

Loughran, J. J. (2010). What expert teachers do: Enhancing professional knowledge for classroom practice. Sydney: Allen \& Unwin.

Mackeracher, D. (2004). Making sense of adult learning. Toronto: University of Toronto Press.

Miles, M., \& Huberman, M. (1994). Qualitative data analysis. London: SAGE Publications.

Newby, D. (2003). The interface between theory and practice. In D. Newby (ed.), Mediating between theory and practice in the context of different learning cultures and languages (pp. 15-22). Strasbourg: Council of Europe Publishing.

Papastamatis, A., \& Panitsidou, E. (2009). The aspect of accessibility to in the light of European lifelong learning strategies. Adult Education Centres: A case study. International Journal of Lifelong Education, 28(3), 335-351.

Pellicer, L. O., \& Anderson, L. W. (1995). A handbook for teacher leaders. London: Sage Publications.

Queeny, D. S. (2000). Continuing professional education. In A. Wilson and E. Hayes (eds.), Handbook of Adult and Continuing Education (pp. 375-391). San Francisco, CA: Jossey-Bass.

Richards, J. C. (2001). Curriculum development in language teaching. Cambridge: Cambridge University Press.

Richards, J. C., \& Farrell, T. S. C. (2005). Professional development for language teachers: strategies for teacher learning. Cambridge: Cambridge University Press.

Rogers, A. (1996). Teaching adults. Buckingham: The Open University Press.

Sava, B. (2009). Role of functional academic literacy in ESP teaching: ESP teacher training in Turkey for sustainable development. Journal of International Social Research, 9 (2), 395406.

Sesek, U. (2007). English for teachers of EFL-toward a holistic description. English Specific Purposes, 26 (4), 411-425. 
Wang, L. Y. (2013). Non-native EFL teacher trainees' attitude towards the recruitment of NESTs and teacher collaboration in language classrooms. Journal of Language Teaching and Research, 4 (1), 12-20.

West, R. (1994). Needs analysis in language teaching. Language Teaching, 27(1), 1-19.

Wu, H., \& Badger, R. (2009). In a strange and uncharted land: ESP teachers' strategies for dealing with unpredicted problems in subject knowledge during class. English for Specific Purposes, 28(1), 19-32.

Zhu, W., \& Liao, F. (2008). On differences between general English teaching and business English teaching. English Language Teaching, 1(2), 90-95.

Dora Chostelidou is a researcher and Ph.D. candidate in Applied Linguistics at the Aristotle University of Thessaloniki. She has participated in various projects and international conferences and she has been author or coauthor of papers in journals, collected editions and conference proceedings .

Dr. Eleni Griva is an Assistant Professor at the Faculty of Education - University of Western Macedonia. Her research interests include: L2/FL Learning and Teaching, Language learning strategies, Bilingualism/multilingualism, Language policy. She has published three books, and she has been author or coauthor of over 100 papers in journals, collected editions and conference proceedings and she has participated in various projects and international conferences. 